\title{
THE EMERGENCE OF NEW SANTRI IN INDONESIA
}

\author{
Yon Machmudi \\ The University of Indonesia, Jakarta
}

\begin{abstract}
To an extent never seen before, following the collapse of the Soeharto regime in 1998 Islamist groups in Indonesia began to express themselves vocally and explicitly. Islamic discourse has developed apace, ranging from demands that the state lift the ban on the role of Islamic ideology in political parties and mass organizations to accommodate Muslim interests up to calls for the implementation of Islamic shari ath to replace the so-called secular laws of state. These recent phenomena indicate the emergence of new santris (devout Muslims) differing from their own parents and the older generation in terms of political orientation, religious ideology, and attitude towards inherited traditions. These new types of santri are not only influenced by the local and changing dynamics of Indonesian politics, society and culture but they are also subject to international influences in Islam. Within Indonesia, some of them retain their links with traditionalist or modernist groups, some others keep their distance from them and yet still others show radical orientations. They have become very influential within certain sections of Indonesian society and have gained attention from many observers and researchers.
\end{abstract}

Keyword: Convergent santri, radical santri, global santri, religious ideology.

\section{Introduction}

This paper analyses the early development of the new santri during the time of the consolidation of Soeharto's New Order up until its collapse in 1998. We introduce three types of new santri: convergent, radical and global. While these are not rigid classifications, the three variants can be explained by affiliation with different groupings within Indonesian Islam. Santri described as "convergent" are both 
traditionalist and modernist activists who tend to merge with each other. The "radical" santri are usually pessimistic about the traditionalist and modernist struggles in Islam and demand radical change in Indonesia. The "global" santri are more influenced by trans-national movements in the Middle East, yet still form part of both traditionalist and modernist groupings at home. Our approach is based on an analysis of the doctrinal origins and the religious agendas of these contemporary santri in order to better understand the emergence of the Jemaah Tarbiyah. The activists of PKS are mainly drawn from members of Jemaah Tarbiyah, who fall into the category of global santri.

An identification of the santri in Indonesia was made through the useful work of the anthropologist, Clifford Geertz. In his study of the religious life in the town of "Mojokuto", East Java, during the 1950s, Geertz classified the Javanese into three variants, priyayi, santri and abangan. Although his work has drawn criticism from many scholars, the santri-abangan dichotomy is still important for an understanding of the religious and political orientations of Muslims in Indonesia. Santri, or observant Muslims are further divided into two groups, kolot (traditionalist) and moderen (modernist). ${ }^{1}$ The former, following Geertz, accommodated local practices and rituals in their Islam and affiliated politically with Nahdlatul Ulama (NU) whilst the latter were determined to purify Islamic teachings from local syncretic practices and preferred to join Masyumi. ${ }^{2}$

About twenty years later, another distinction between traditionalist and modernist was made by Allan A. Samson. He described them as politically accommodationist or reformist in nature. Samson then added a further type of santri, which he named "radical fundamentalist". This new category is indeed helpful for our understanding of the reality of santri in Indonesia, in addition to the two already acknowledged variants. ${ }^{3}$ The fundamentalist element of santri was attributed to the Darul Islam movement of the 1950s, which launched a rebellion against the new Indonesian state, aiming to

\footnotetext{
${ }^{1}$ Clifford Geertz, The Religion of Java (New York: the Free Press, 1960), p. 129.

2 Ibid., pp. 148-176

3 Allan S. Samson, "Army and Islam in Indonesia," Pacific Affairs 44 no. 4 (Winter 1971-1972), p. 549.
} 
establish an Indonesia Islamic State. ${ }^{4}$ The continuation of fundamentalist groups from the past, as classified by Samson, bears a correlation to radical groups of the present which has contributed to violent actions. In this thesis we call this category of santri, "radical" santri.

However, merely relying on the received insights of Geertz, Samson and other scholars will not provide us with a satisfactory picture of the recent face of Islam in Indonesia. Various events have taken place since the New Order period, which have changed the face of the old santri; a new concept, which I present in this article, is needed to explain these recent developments.

\section{Factors behind the Emergence of New Santri}

The emergence of the new santri dates from the 1970s, when the younger generation of Indonesian Muslims began to demonstrate a growing distance from their elders. This phenomenon resulted either in the process of convergence between traditionalism and modernism or in a process of alienation. The former contributed to a new strategy in promoting Islam through democratic structures, while the latter tended towards a radical orientation. The New Order regime's repression of political Islam, the extension of religious education in public schools and the prominence of international events in the Middle East were important factors contributing to the gulf between the younger generation and their predecessors.

Repression and the Failure of Political Islam

The two-pronged policy of the New Order towards Islam in Indonesia was responsible for the decline of the forces of political Islam. The regime repressed "organised Islam" and maintained cooperation with and co-option of Islamic representation that was non-political in nature. It was eager to exclude politicised Muslims because of the threat to the stability of the regime, should they increase their influence in society and in government affairs. ${ }^{5}$ Since Muslim politicians enjoyed "genuine popular support", they indeed posed potent threats. On the other hand, nominal Muslims accused them of

\footnotetext{
${ }^{4}$ Ibid.

${ }^{5}$ Harold Crouch, "Islam and Politics in Indonesia," in Politics, Diplomacy and Islam: Four Case Studies (Canberra: Department of International Relations, The Australian National University, 1986), p. 15.
} 
having an agenda to establish an Islamic state and to impose the sharith on those who did not wish to comply with the tenets of Islam. ${ }^{6}$ The heavy-handed policies of the New Order towards political Islam led some Muslims to adopt a more pragmatic approach, avoiding formal political struggle and turning instead to cultural and social activities. Some of them even preferred to join government-sponsored associations and to become outright supporters of the regime.

To cast our eyes further back in time, the fall of Soekarno and the establishment of the New Order in 1966 were welcomed optimistically by former members of Masyumi, which had been banned by Soekarno. In their view, the New Order promised to accommodate the forces of Islam, since they had contributed to the campaign to destroy the Communist Party of Indonesia. Islamic groups, particularly the modernists, hoped that the new regime would open up political opportunities to them. In August 1966, thousands of Muslims attended a public gathering held in Jakarta's al-Azhar mosque, welcoming the release of political prisoners such as Hamka, Isa Anshary and Burhanuddin Harahap. ${ }^{7}$ Other important figures, such as Syafruddin Prawiranegara, Prawoto Mangkusasmito, Mohamad Roem, Kasman Singodimejo and M. Natsir appeared and gave orations appealing to the government to immediately rehabilitate Masyumi.

The demands of the modernist activists did not gain much attention from the government, however. The military-backed regime affirmed its stance that its ally, the army, would not allow any political groups which had carried out "illegal actions and rebellion" against Pancasila and the Constitution of 1945. The Communists, Darul Islam, Masyumi and the Indonesian Socialist Party (Partai Sosialis Indonesia PSI) were counted among such dissenting groups. ${ }^{8}$

In preparing a new Islamic party, some former activists of Masyumi established a Co-ordinating Forum for Muslim Action (Badan Koordinasi Amal Muslimin, BKAM) and, with the support of sixteen other Islamic organizations, proposed a new political party, Partai Muslimin Indonesia (Parmusi). In February 1967 the ruling elite

\footnotetext{
${ }^{6}$ Guy J. Pauker, "Indonesia in 1980: Regime Fatigue?” Asian Survey 21 no. 2 (February 1981), p. 240.

7 B.J. Boland, The Struggle of Islam in Modern Indonesia (The Hague: Martinus Nijhoff, 1971), p. 148.

${ }^{8}$ Ibid.
} 
permitted the establishment of Parmusi but rejected the involvement of former Masyumi figures. The establishment of Parmusi was "recompensed" by the appointment of a Parmusi chairman who was chosen by the regime itself. The 1971 general elections then showed an ineffective performance by the party, when it gained only about $5 \%$ of total votes, far below the achievement of the traditionalist party of Nahdlatul Ulama (19\%).

The success of the new regime in controlling modernist Muslim activists was followed by repression towards traditionalist groups as well. The NU, which had maintained a good rapprochement with the Old Order regime, had immediately joined forces with the army against the PKI during the tragic bloodshed of 1965. Even though NU was able to cooperate with other parties, including the PKI, under the Guided Democracy of Soekarno, in fact at the grassroots, members of NU were in deep conflict with the Communists. When armed clashes took place, NU was among those who harshly attacked Communist sympathisers. However, events around the 1971 general elections showed political competition between NU and the regime's party, Golkar, which involved a terrorising of NU, when many NU campaigners were kidnapped and tortured by the supporters of the regime. ${ }^{9}$ NU then shifted its attitude from collaboration to confrontation, a turnabout that caused the government to respond by hardening its stance towards NU and the Muslim community in toto. ${ }^{10}$

Under these conditions, the shift of the Islamic struggle from political into cultural orientations, focussing on intellectual life or on predication, enabled the two opposed traditionalist and modernist groups to encounter each other and to develop social networks. While the intellectually-oriented group tended to denounce Islamic parties, the predication-oriented group, with its non-partisan strategy, further chose not to vote during the general elections as golput (golongan putih, non voters). Thus it was that the two generations of traditionalists and modernists found themselves inclined to merge. They were able to dissolve the schism between traditionalist and modernist santri through

\footnotetext{
${ }^{9}$ Ken Ward, The 1971 Election in Indonesia: An East Java Case Study (Clayton: Centre of Southeast Asian Studies Monash University, 1974), p. 112.

${ }^{10}$ Robert W. Hefner, Civil Islam: Muslim and Democratisation in Indonesia (Princeton and Oxford: Princeton University Press, 2000), p. 92.
} 
intra-organisational interaction, developing a growing acceptance of the idea that the truth might lie in synthesis rather than in antithesis. ${ }^{11}$

\section{The Impact of Religious Education}

Despite its policies adverse to politically organised Islam, the New Order regime served to expand the social role of Islam in other ways. The Soeharto government offered considerable support to missionary activities and religious education. Robert W. Hefner has presented a remarkable counter example of the process of Islamisation in his research on the region of Tengger in East Java. ${ }^{12}$ Bambang Pranowo has also illustrated a similar trend in a rising Islamisation in Central Java during the era of political restriction on the santri in general. ${ }^{13}$

The double-edged policy of the New Order government towards Islam has created many speculations of its motives. Yet it was not a new policy. During the first half of the $20^{\text {th }}$ century the Dutch colonial government of the East Indies practised precisely the same policy when it made the distinction between Islam as a religion and Islam as politics. The difference is that the Dutch government did not support the growth of Islam among the Indonesian people, while the Soeharto government did indeed cultivate a process of Islamisation. ${ }^{14}$

The establishment of the Ministry of Religious Affairs, Departemen Agama (Depag) was part of the role of the government to promote Islam. ${ }^{15}$ The function of this ministry was to ensure and preserve practice and belief within the five formal religions recognised in Indonesia. The first pillar of Pancasila, "the Oneness of God", reflects the implicit responsibility of the state in maintaining the existence of these religions. Even though the Ministry of Religious Affairs was charged to serve the interest of all religions, since Islam is

11 R. William Liddle, "The Islamic Turn in Indonesia: a Political Explanation," The Journal of Asian Studies 55, no. 3 (August 1996), p. 623.

12 Robert W. Hefner, "Islamising Java? Religion and Politics in Rural East Java," The Journal of Asian Studies 46 no. 3 (1987), pp. 533-554.

13 Bambang Pranowo, "Islam and Party Politics in Rural Java," Studia Islamika I no. 2 (1994), pp. 1-19.

${ }^{14}$ For further details about the Dutch policies in Indonesia, see Harry J. Benda, "Christian Snouck Hurgronje and the Foundations of Dutch Islamic Policy in Indonesia," The Journal of Modern History 30 no. 4 (December 1958), pp. 338-347.

15 The establishment of Depag has been also considered as a political compensation for Muslims after the defeat of the Jakarta Charter (Piagam Jakarta). 
embraced by the majority, it is obvious that the ministry became an affective agency in carrying out the agenda of Islamisation. During the 1950s and the 1960s much attention was given to the organization, education and internal reinforcement of the Muslim community, as well as to the spread of Islam to the non-literate parts of the country. The Christians initially did not like the Ministry and opposed the intervention of the government in their affairs. Hinduism and Buddhism obtained a directorate within the Ministry not long after the late 1950s. ${ }^{16}$

Few can deny that this ministry has served the interests of the santri at the levels of both government and grassroots. ${ }^{17}$ Nevertheless, B.J. Boland has disagreed about any dominant role of Islam within the Ministry of Religious Affairs and has argued that the department has served as an important medium in resolving problems between Islamic and secular oriented groups in the heated debate over the foundations of the Indonesian state. ${ }^{18}$ The involvement of the government in the area of religious practice among its citizens has contributed to eliminating barriers among the adherents of five legal religions in Indonesia. ${ }^{19}$

One of the main implementations of state support is to ensure that students in public schools and universities receive religious education from teachers of their own religion. However, the commitment of the government to promote religion in educational institutions was a longstanding one, dating from the 1950s. It was Soekarno who issued the governmental decision Peraturan Pemerintah (Perpu) No. 4/1950, regulating universal instruction in religion through the collaboration of both the Department of National Education and the Department of Religious Affairs. ${ }^{20}$

President Soeharto confirmed this regulation at a meeting of People's Consultative Assembly, Majelis Permusyawaratan Rakyat (MPR) in 1966. It is stated that religious education is a core subject for

\footnotetext{
${ }^{16}$ Jacques Waardenburg, "Muslim and Other Believers: The Indonesian Case" in Islam in Asia II (Boulder: Westview Press, 1984), pp. 32-33.

17 Geertz, The Religion of Java, p. 200.

18 Boland, The Struggle of Islam, p. 105.

${ }^{19}$ Ibid.

${ }^{20}$ Ibid., p. 110
} 
all students from primary school to university. ${ }^{21}$ Recently, on 11 June 2003 through debate and rejection from non-Muslim schools, this regulation has been validated by the government as the System of National Education Law (Undang-Undang Sistem Pendidikan National, UU Sisdiknas). ${ }^{22}$ This policy has brought about change in religious trends within schools and universities, so that many students have been able to learn and practise their religion. Along with the facilitation of religious instruction in public schools, religious activities involving students and teachers both have become more apparent. For instance, students may celebrate the high religious days (Hari-Hari Besar Keagamaan) and observe their religious obligations during the course of their studies.

The vital role of the Ministry of Religious Affairs in providing and supervising religious courses has made this ministry an arena of conflict between traditionalist and modernist Muslim groups. Motivated by the need to preserve their specific religious practices, which are based on the jurisprudential schools (madhhab), both traditionalists and modernists are in competition to secure the position of Minister of Religious Affairs for one of their own. Holding the position of Minister means securing more influence over thousands of teachers who are responsible for delivering the religious message to students. When, in 1971, NU lost the top leadership of the Ministry of Religion, its influence over religious training in the primary schools gradually diminished. Religious courses of instruction and textbooks published by the Ministry of Religion were perceived by the traditionalist group as substantially promoting non-traditionalist views. ${ }^{23}$

However, teachers of religion in primary schools have the right to teach Islam in a way that is suited to their students. The teaching of religion in the universities is more open and might well accommodate both traditionalist and modernist views of Islam. Lecturers are not able to impose their own understanding of religious matters, rather it is

\footnotetext{
${ }^{21}$ Ibid.

22 See "Tidak Mudah Bagi Pemerintah Penuhi Amanat UU Sisdiknas," Kompas, 17 June 2003.

${ }^{23}$ Andree Feillard, "Traditionalist Islam and the State in Indonesia" in Islam in an Era of Nation States:Politics and Religious Renewal in Muslim Southeast Asia (Honolulu: University of Hawaii Press, 1997), p. 143.
} 
expected that they maintain a balance and discuss fairly the various understandings of Islam.

Through their religion classes, university students are no longer concerned with sectarian differences and tend to share traditionalist and modernist practices equally. Thus government policy has been responsible for the dilution of traditionalist-modernist antipathies. Students tend to practise Islam in simple ways that are suited to their needs. Since the campuses also provide many extra-curricular Islamic training courses and activities, students are at an increased risk of being diverted from mainstream Islam. They feel no need to visit mosques outside their campus to interact with traditionalist or modernist organizations. ${ }^{24}$ However, since they are not sufficiently trained in traditional and classical Islam, the chief the methodological avenues in deriving the laws of Islamic jurisprudence, they tend to be more literal in their understanding of Islam..$^{25}$

In the 1980s, Islamic student organizations were barred from the campuses. The Islamic Students Association, Himpunan Mahasiswa Islam (HMI) which had been very prominent during the 1960s and 1970s, was no longer able to recruit the best students from the prestigious secular campuses. ${ }^{26}$ Leading student association figures became more interested in organisational issues and campus politics in order to control student executives, abandoning their duties of religious training and predication. ${ }^{27}$

However, it was not only Muslim groups that saw the Minister of Religious Affairs as a crucial post, the regime also found that the ministry was a significant tool of intervention in the daily affairs of Indonesian Muslims. Since the Soeharto regime was able to control the department, its minister could be kept in line with the government's national policies. Soeharto discarded the influence of Islamic forces, traditionalist or modernist, by appointing the minister from elsewhere the professional class, or even from the ranks of the armed forces. ${ }^{28}$

\footnotetext{
${ }^{24}$ Kuntowijoyo, Muslim Tanpa Masjid (Bandung: Mizan, 2001), p. 133.

25 Azyumardi Azra, "Islam in Southeast Asia: Tolerance and Radicalism" (Paper presented at The University of Melbourne, 6 April 2005), p. 5.

${ }^{26}$ Liddle, “The Islamic Turn, ” p. 625.

${ }^{27}$ Interview with Nur Mahmudi, Depok, 8 May 2003.

28 Sidney Jones, "It Can’t Happen Here: A Post-Khomeini Look at Indonesian Islam," Asian Survey 20 no. 3 (March 1980), p. 319.
} 


\section{International Influences}

The encounter of Indonesians with global issues and ideas occurred not only in the 1980s, particularly after the 1979 Iranian Revolution, but it had developed centuries ago. Historically, since the late 15th century it was the bramayn, the two holy Arabian cities of Mecca and Medina that were considered to be the hub of the global network of Islam. ${ }^{29}$ Scholars in both cities developed their authority throughout the Muslim world. They not only judged to issues within their region but also gave responses to many questions sent by Muslims from around the world. Contact between Muslims of the Indonesian archipelago and the Middle East had become significant since the late $16^{\text {th }}$ century and developed intensively in the late $19^{\text {th }}$ century. ${ }^{30}$ Certain Meccan scholars, for instance, were involved in religious issues arising in Indonesia, including the sending of a decree to topple a woman, Sultanah Kamalat Syah of Aceh of the late of $17^{\text {th }}$ century, from rule in accordance with the prohibition against a woman leading a kingdom. ${ }^{31}$ The capacity of Indonesian Muslims to accommodate foreign and local elements together resulted in the internalising of the global element into local beliefs. Indonesian Islam was thus distinct in nature in from its Middle Eastern counterpart. ${ }^{32}$

Since the 1980s, the global influences of Islam on Indonesian Muslims have become more apparent. This "globalised" phenomenon of Indonesian Islam is the result more of a direct imitation of international orientations than a reliance on local traditions. Sociopolitical events in the Middle East, including religious conflicts and scholarly schisms, have had a large impact upon Indonesian Muslims.

Since the adoption of international ideas is not monopolised by any single figure or source of religious authority, their manifestations in Indonesia have been varied. Middle-East-replicated movements have mushroomed in Indonesia, each developing its own channels of contact and networks with Egypt, Yemen, Jordan, India and Pakistan. The emergence of movements such as the Muslim Brothers (Egypt), the Salafi groups (Saudi Arabia), Hizbut Tahrir (Jordan) and Jemaah

\footnotetext{
29 Azyumardi Azra, Jaringan Global dan Lokal Islam Nusantara (Bandung: Mizan, 2002), p. 64.

30 Azra, "Islam in Southeast Asia," p. 7.

31 Azra, Jaringan Global dan Lokal Islam Nusantara, p. 67.

32 Ibid., p. 18.
} 
Tabligh (Indo- Pakistan) are significant evidence that trans-national movements have seeded their influences in Indonesia.

Historically, the more apparent influence of the Middle East-based movements in Indonesia was due to the outreach of Dewan Dakwah Islamiyah Indonesia (DDII) under the leadership of M. Natsir, who personally established good relations with Middle Eastern leaders. Concerned about the expansion of the renewal movement and its secular orientation, DDII sent many students to study in Middle Eastern universities, in order to balance the Ministry of Religious Affairs' program led by Munawir Syadzali (1983-1993) who preferred to send young scholars to educational institutions in the United States and to Western Europe. ${ }^{33}$ Barred from domestic political participation, Natsir earned a high reputation in Middle-East Muslim countries. He has won credentials recognised by most international Muslim leaders and DDII has benefited from connections with donors in Saudi Arabia, Kuwait and Pakistan to finance its domestic programs. To some extent, the sponsorship of DDII has meant that hundreds of Indonesian students have obtained international degrees, in turn helping to maintain cadres who are committed to global awareness and to anti-liberal Islam. ${ }^{34}$ Since the 1970s and 1980s, the oil boom has permitted more funds for religious scholarship programs and the number of Indonesian students in Middle-Eastern countries has multiplied.

The era since the 1970s has also witnessed the translation of hundreds of books from Arabic into Indonesian. In Nasir Tamara's observations of the 1980s Islamic revival, he was amazed at the numbers of Islamic publications and the extent of publishing activity. Most books were not just about ritual obligations but carried a concern for social and political problems as well. For instance, translations of the writings of Sayyid Qut\} were very popular. ${ }^{35}$ Subsequently, during the mid-1980s, the influence of the Muslim Brotherhood's ideas was not confined to the medium of translated of books, but direct personal

\footnotetext{
${ }^{33}$ Robert W. Hefner, Civil Islam: Muslims and Democratization in Indonesia (Princeton and Oxford: Princeton University Press, 2000), p. 110.

${ }^{34}$ Ibid.

35 Nasir Tamara, Indonesia in the Wake of Islam: 1965-1985 (Kuala Lumpur: Institute of Strategic and International Studies, 1986), p. 6.
} 
contact between Indonesian students and Middle Eastern mentors was also very likely to occur. ${ }^{36}$

The homecoming of Middle Eastern graduates and their interactions with the younger Muslim generation in the secular campuses of Indonesia introduced more comprehensive and systematic models of Islamic movements and thought. The Middle Eastern graduates became actively involved in predication, preferring neither to become government employees nor to return to their old Islamic institutions (pesantren) to teach. They remained independent and set up their own Islamic institutions, called ma had, in urban centres where they became involved in providing informal religious instruction to students in their surrounds. Rahmat Abdullah, a Jemaah Tarbiyah activist, acknowledged the role of one Middle Eastern graduate:

In 1980, my teacher returned from his study in Egypt. He had joined IM [Ikhwanul Muslimin, The Muslim Brothers] training, and had brought back many IM books. One of his books was written by Sayyid Hawa [and translated to Indonesian as] Risalah Perjuangan (Message of Struggle). My teacher and I then established an Islamic boarding school, Rumah Pendidikan Islam Darut Tarbiyah (the House of Islamic Education)... ${ }^{37}$

\section{Variants, Characteristics, and Groupings}

Viewing the 1970s and 1980s political and intellectual phenomena among Indonesian Muslims, Syafii Anwar indicated the significant growth of a younger generation that differed from their predecessors. He called this new type of santri "neo-santri". While the "old santri" kept their links with established Islamic parties and groupings, the "neo-santri" are identified by their disengagement from political activity. ${ }^{38}$ In general, what Anwar means by "old santri" is the grouping of political Islam, whilst "neo-santri" stands for cultural Islam. In addition, the neo-santri, according to Anwar, has not directly experienced the political repression of the New Order regime; they learned politics chiefly from their involvement with Islamic student

\footnotetext{
${ }^{36}$ Interview with Sholeh Drehem, Surabaya, 13 March 2003.

${ }^{37}$ Interview with Rahmat Abdullah, Jakarta, 11 May 2003.

38 Syafii Anwar, Pemikiran dan Aksi Islam Indonesia: Sebuah Kajian Politik Tentang Cendekiawan Muslim Order Baru (Jakarta: Paramadina, 1995), pp. 128-133.
} 
organizations. ${ }^{39}$ They have not held hard and fast attitudes on ideology, but have inclined towards more pragmatic, rational and receptive approaches. Their attitude towards Islam is based on its substance and functions, not on Islamic symbols or a literal understanding of texts. The new santri, Anwar claims, are the new Muslim middle class and the embryo of what he calls "cendekiawan muslim" (Muslim intellectuals) who were later to form the organization, Indonesian Muslim Intellectual Association, Ikatan Cendekiawan Muslim Indonesia (ICMI). ${ }^{40}$

However, Anwar appears not to have been aware of the different character of the new santri that developed within the university campuses after the mid 1980s. The neo-santri variant as described by Anwar puts more emphasis on only one side of the convergence phenomenon, that is, the intellectual convergence between the traditionalist NU and the modernist Muhammadiyah, which has lessened the differences between them. He pays little attention to the development of the predication movement, which is quite separate from the renewal movement in its orientation. This is the specific character of younger Muslims who have not only loosened their ties with both NU and Muhammadiyah but also show a tendency to be attracted to international ideas. All of these different variants, characters and groups of new santri deserve more elaboration in explaining the phenomena of contemporary Islam in Indonesia.

Table 1: Attitudes of New Santri in Indonesia

\begin{tabular}{llllll}
\hline \hline $\begin{array}{c}\text { Types of } \\
\text { New } \\
\text { Santri }\end{array}$ & $\begin{array}{c}\text { Mainstream } \\
\text { Scholars }\end{array}$ & $\begin{array}{c}\text { Traditionalist } \\
\text { and } \\
\text { Modernist } \\
\text { Practice }\end{array}$ & $\begin{array}{c}\text { Salafus Salih } \\
\text { (trustworthy } \\
\text { ancient } \\
\text { scholars) }\end{array}$ & $\begin{array}{c}\text { Muslim } \\
\text { world } \\
\text { issues } \\
\text { critical }\end{array}$ & Democracy \\
\hline \hline $\begin{array}{l}\text { Convergent } \\
(1970 \mathrm{~s})\end{array}$ & Critical & Agree & Critical & Critical & $\begin{array}{l}\text { Strongly } \\
\text { agree }\end{array}$ \\
\hline Radical & Strongly & Disagree & Strongly & Agree & $\begin{array}{l}\text { Strongly } \\
\text { disagree }\end{array}$ \\
\hline (1980s) & disagree & agree & Agree & Strongly & Critical \\
\hline $\begin{array}{l}\text { Global } \\
(1990 \mathrm{~s})\end{array}$ & Critical & Critical & agree & \\
\hline \hline
\end{tabular}

Level of acceptance : (1). Strongly Agree; (2). Agree; (3). Critical; (4). Disagree; (5). Strongly disagree.

\footnotetext{
${ }^{39}$ Ibid.

40 Ibid.
} 
The table 1 shows the types of new santri in Indonesia, their character and attitudes toward traditionalist and modernist traditions. It also shows how they are diverse in responding contemporary issues, including democracy.

\section{Convergent Santri (the 1970s)}

To some extent, the convergence between traditionalist and modernist groups signified the trend of new generation of Indonesian Muslims in the 1970s. They initiated modifications in religious practices and sought to enrich their understanding of Islam by reading alternative Islamic books from overseas (Middle East and the West). ${ }^{41}$ In addition, having witnessed the poor relations between the regime and Muslim activists, which were due to the unwillingness of the New Order regime to accommodate their political interests, the new generation of Indonesian Muslims in the 1970s, particularly the modernists, focussed their energy into two types of activities: renewal and a missionary movement. Many Islamic activities were embarked upon, such as discussion groups, seminars and dialogue that brought figures from both traditionalist and modernist camps to discuss Islamic and national issues. More and more, the younger generation were involved in formal and informal meetings to discuss Indonesian and Islamic issues in a broad context. ${ }^{42}$

a) Renewal Movement

Initiated by Nurcholish Madjid, the chairman of the Muslim Student Association, Himpunan Mahasiswa Islam (HMI) the advent of the renewal movement in the 1970s gained momentum and drew much attention from Muslim activists who had become disinclined to continue the struggle of Islam through political party channels. ${ }^{43}$ They changed their structural approach into a more cultural one, from a symbolic and formalistic approach to a substantive one. By promoting political accommodation, the prevailing tension between Muslims and the regime was gradually reduced. It was this cultural method of

\footnotetext{
${ }^{41}$ Kuntowijoyo, "Konvergensi Sosial dan Alternatif Gerakan Kultural," Pesantren 3 no. 3 (1986), pp. 6-7.

42 Anwar, Pemikiran dan Aksi Islam di Indonesia, p. 125.

${ }^{43}$ Nurcholish Madjid was considered as the pioneer of the Islamic renewal movement. See Bahtiar Effendy, Islam dan Negara: Transformasi Pemikiran dan Praktik Politik Islam di Indonesia (Jakarta:Paramadina, 1998), p. 136.
} 
cooperation that enabled Muslims to influence the existing political system from within. ${ }^{44}$ Bachtiar Effendy pointed out that this change led to what he called the emergence of a "new Islamic intellectualism" in Indonesia. According to Effendy, the movement contributed to better relations between Muslims and the regime by focussing on three activities-religious renewal, political reformism and social transformation. 45

Religious renewal was carried out in an effort to solve theological and philosophical problems of political Muslims in their relations with the state. The understanding of the old generation of Muslims towards the lack of separation between Islam and the state was the main concern for the renewal group. Effendy explains that the older theological stance, which tended to be more formalistic, legalistic and literal to the younger generation needed to be adjusted to respond to the social and political realities in Indonesia. They did not intend to change the doctrines of Islam, but rather to mount an effort to refresh Muslims' understanding of their religion. They did not believe that Islam constitutes an ideology, since the Qur'an and Hadith do not command Muslims to establish a state based on Islamic ideology. Therefore, Muslims had to be committed to the universal values of Islam, not to institutions and organisations, including political parties. ${ }^{46}$

In addition, in order to revise critical relations between the state and Islam, the renewal movement's solution was through involvement within the system. This political reformism meant that Islam should not represent an oppositional force against the state; the most important effort for Muslims was to push the state to guarantee their freedom in observing Islamic teachings. These required its activists to play a role in the policy making process by joining the state's bureaucrats and political parties. ${ }^{47}$

This approach brought a significant change that led most former activists of Islamic organisations to accept the ideology of Pancasila

\footnotetext{
${ }^{44}$ Anwar, Pemikiran dan Aksi Islam di Indonesia, p. 8.

${ }^{45}$ Effendy, Islam dan Negara, p. 125.

46 Ibid., p. 136.

${ }^{47}$ Ibid., p. 155.
} 
and some even became part of the regime. ${ }^{48}$ The chairman and secretary-general of the Partai Muslimin Indonesia (Parmusi), Mintaredja and Sulastomo, served as the Minister of Social Affairs and was a bureaucrat in the Soeharto regime during the 1970s. After that other former Muslim activists have joined the regime. Among them were Sularso, Bintoro Tjokroaminoto, Barli Halim, Bustanul Arifin, Madjid Ibrahim, Norman Razak, Zainul Yasni, Omar Tusin, Sya'adilah Mursid, Mar'ie Muhammad, Hariry Hadi and many others. ${ }^{49}$ In fact, their involvement within the system has not only brought about reconciliation between the state and Islam but also contributed to the bringing together other elements of Muslim forces from various backgrounds to exert influence on the state.

Another aspect of the renewal movement was the social transformation movement. The transformation movement aimed to strengthen the capacity of society in terms of social, cultural, political and economic improvement. Since the New Order regime was so effective in controlling the socio-political dimensions of the people at the grassroots, the transformation movement had to build communication and cooperation with the regime's apparatus in order to run their programs. ${ }^{50}$ In addition, this approach also created good relations between traditionalist and modernist groups. Dawam Rahardjo, Sudjoko Prasodjo, and Adi Sasono were among the pioneers of the social transformation movement. For instance, the Institute of Social and Economic Research, Education and Information, Lembaga Penelitian, Pendidikan dan Penerangan Ekonomi dan Sosial (LP3S) was established in 1971 to strengthen the role of society and has become an important avenue for traditionalist and modernist activists to cooperate each other.

Many figures from modernist-affiliated movements have supported the idea of renewal Islam, such as Usep Fathuddin dan Utomo Dananjaya from the Indonesian Muslim Students, Pelajar Islam Indonesia (PII), Dawam Rahardjo, Djohan Effendi and Ahmad Wahib from the "limited group" discussions in Yogyakarta. Although the

48 The spirit of reconciliation between the state and Islam evinced by Muslims' acceptance of the ideology of Pancasila not only prevailed within modernist circles but was also followed by traditionalist organisations.

${ }^{49}$ Effendy, Islam dan Negara, p. 163.

${ }^{50}$ Ibid., p. 165. 
traditionalist camp had been absent in the earliest days of the discourse, many from a traditionalist background subsequently contributed to shaping and expanding the new intellectual orientation after the arrival home of Abdurahman Wahid in 1971 from his study in Baghdad. Through discussions and intellectual exercises among the new generation of santri in the 1970s, those involved succeeded in bringing Muslim resources together and contributing to the Indonesian developmental program. This was the arena of the phenomenon of convergence, in which traditionalist and modernist views and groups reached mutual understanding and cooperation. These younger Muslim intellectuals held regular series of discussion in Jakarta. ${ }^{51}$ As former chairman of HMI, Nurcholish Madjid enjoyed good relations with influential figures from the modernist Masyumi, whilst Abdurahman Wahid had impeccable "blue blood" (darah biru) in the eyes of traditionalist NU stakeholders. ${ }^{52}$

Criticism has been directed towards the renewal movement and other associated movements, because they have not engaged with wider public issues but tend to be elite and urban oriented. They have not been able to reach the Muslim grassroots, most of the Indonesian people. In order to be understood by ordinary Muslims, their discourse has needed to be "translated" by a second layer of spokesmen. ${ }^{53}$ For this reason, Islamic predication movements emerged to respond the needs of grassroots in understanding Islam.

b) Predication Movement

The predication movement represents yet another type of convergent santri. Disillusioned by the failure of their efforts to resurrect the Islamic party of Masyumi, certain modernist Muslims, led by M. Natsir, embarked on programs of propagation and predication. In May 1967 Natsir established an Islamic missionary institution, called the Indonesian Islamic Missionary Board, Dewan Dakwah Islam

51 Greg Barton, "Islam and Politics in the New Indonesia," in Islam in Asia Changing Political Realities (New Brunswick and London: Transaction Publishers, 2002), p. 19.

52 Recent developments of this santri stream have generated two further and complicated trends of neo-traditionalism and neo-modernism. The Liberal Islam Network, Jaringan Islam Liberal (JIL) and the Muhammadiyah Young Intellectual Network, Jaringan Intelektual Muda Muhammadiyah (JIMM) are recent phenomena resulting from the long intellectual journey of the renewal movement.

53 See Tempo, 3 April 1993. 
Indonesia (DDII). By promoting Islamic preaching, activists of DDII hoped to persuade more Muslims to be aware of their religious and political obligations as citizens. Since they were unable to participate in formal political activity or to take part in influencing the state, da wah activity became an alternative strategy to prepare cadres who would struggle for Islam in the future. It was believed that this kind of predication project would have a longer-term impact on the formation of the national leadership in Indonesia. As stated in the organisational goals of DDII, the institution itself originally aimed to serve as "laboratory and consultation for the effective propagation of Islam in modern society." 54 The inclination of the organization to become engaged in political issues has contributed to the weakening of its progress in general. 55 Nevertheless, DDII became fertile ground to seed oppositional attitudes against the New Order regime.

To realise its long-term goals, DDII needed to improve the social and educational levels of Muslim communities. DDII then worked closely with the Medical College of the Islamic Hospital Foundation, Yayasan Rumah Sakit Islam (Yarsi), a modernist oriented institution in Jakarta, in providing medical services for the urban poor and in helping to support the development of libraries in mosques, universities and in da wah institutions. In addition to these programs, DDII assisted in developing modernist-oriented pesantren associations in Java and other areas, combining both Islamic and secular subjects. ${ }^{56}$ A private agriculture Pesantren of Darul Falah in Bogor, Dana al-Falah in Bandung, Wisma Tani in Payakumbuh and Yayasan al-Falah in Surabaya are examples of DDII-supported projects that are still well known up to the present time.

Another of the important developments in DDII's predication program was its success in expanding its role in the secular university campuses. DDII held many cadre-training programs in order to support this campus predication. One of these was held in Jakarta, organised by Z.E. Muttaqin and Imaduddin Abdulrahim, both important figures in Masyumi. Since the training took place on the

\footnotetext{
54 Muhammad Kamal Hasan, Muslim Intellectual Responses to New Order Modernisation in Indonesia (Kuala Lumpur: Dewan Bahasa and Pustaka, 1980), p. 70.

55 Ridwan Saidi, "Dinamika kepemimpinan Islam," in Islam in Indonesia: Suatu Ikbtiar Mengaca Diri” (Jakarta: CV Rajawali, 1986), p. 134.

${ }^{56}$ See Hasan, Muslim Intellectual Responses, p. 70.
} 
premises of the Indonesian Pilgrim Committee, Panitia Haji Indonesia (PHI) in Jl. Kwitang, it was called the PHI training. More than 40 delegates, mostly from prestigious universities in Bandung, such as the Institute of Technology of Bandung (ITB), the University of Pajajaran (Unpad) and the Institute of Education (IKIP) attended the training. The recruitment process was conducted through a network of modernist organizations, such as HMI, PII and Muhammadiyah. This PHI training first aimed to provide campuses with religious lecturers to be posted in the state universities and subsequently to become informal liaison officers of DDII on the campuses. ${ }^{57}$

In response to a growing numbers of PHI alumni, a campus network named the Indonesia Campus Mosque Supervision, Bina Masjid Kampus Indonesia (BMKI) was established throughout the universities of Java. Regional coordinators were appointed in order to manage predication programs and communications among the members. There were, for instance, Amien Rais, Kuntowijoyo and M. Mahyuddin as the coordinators for Yogyakarta; Ahmad Sadali, Rudy Syarif Sumadilaga and Yusuf Amir Feisal for Bandung; M. Daud Ali and Nurhay Abdurahman for Jakarta, Halidzi and Abdurrahman Basalama for Ujung Pandang, Kafiz Anwar for Semarang, and AM Saefuddin and Abdul Kadir Jaelani for Bogor. ${ }^{58}$ These leading figures subsequently have been widely acknowledged by university students, from both traditionalist and modernist families alike, as their patrons and main reference.

Within other DDII liaisons, it was Imaduddin Abdurahim who succeeded in expanding campus predication in the 1970s. Besides his involvement in campus networks managed by DDII, Imaduddin initiated mental training sessions at the Institute of Technology in Bandung (ITB). These were called Latihan Mujahid Dakwah (LMD) and succeeding drawing many students into the programs. Their alumni were widespread throughout universities in Java and the outer islands. Until the 1990s, Imaduddin was recognised as the "grand mentor" of Muslim student activists in the secular campuses. In terms of political stance, LMD was similar to DDII, in so far as both became opposition forces against the New Order regime. Imaduddin

\footnotetext{
57 AM Lufhfi, "Gerakan Dakwah di Indonesia," in Bang Imad Pemikiran dan Gerakan Dakwah (Jakarta: Gema Insani Press, 2002), p. 161.

58 Ibid.
} 
developed close contact with M. Natsir. He was not only from a modernist family background but he was active in modernist organizations, such as the Indonesian Islamic Students, Pelajar Islam Indonesia (PII) and the Islamic Student Association, Himpunan Mahasiswa Indonesia (HMI) in Bandung. He occupied a central position on the Board of Muslim Student Proselytising, Lembaga Dakwah Mahasiswa Islam (LDMI) of HMI.

In fact, both the renewal and predication movements contributed to shaping the face of Indonesian Islam, in which young Muslims became more interested in making Islam "more relevant to life in the modern world." 59 They were no longer attracted to either the traditional, ritualistic dogma of the conservative "ulama> or the "messianic fervour of some modernists who want Indonesia to become a theocracy." 60

Radical Santri (the 1980s)

"Radical" here means "favouring or effecting fundamental or revolutionary changes in current practices, conditions or institutions". ${ }^{61}$ The establishment of an Islamic state, therefore, would be the main agenda - to replace the existing state. In contrast, Islamic groups with a belief in the democratic systems, who channel their agendas through political parties and constitutional means, are considered to be "moderate".

Apart from the tendency to merge traditionalist and modernist thought and praxis in Indonesia, there has appeared a generation of Muslims who are disappointed with both of these mainstream views. They have developed their own ideas regarding religious, social and political issues. This type of santri has been much influenced by DI. What is more, this group is best identified by its close relations with ex-leaders of DI. Many reports about them in Indonesian newspapers and magazines have named this phenomenon, emerging since the mid 1970s, in the form of neo-NII (Negara Islam Indonesia, the Indonesia

\footnotetext{
59 Adam Schwarz, A Nation in Waiting: Indonesia's Search for Stability (St. Leonards: Allen and Unwin, 1999), p. 173.

60 Ibid.

${ }^{61}$ The American Heritage ${ }^{\circledR}$ Dictionary of the English Language, 4th ed. (Boston: Houghton Mifflin, 2000).
} 
Islamic State) due to their close doctrinal and ideological affiliations with radical figures of DI. ${ }^{62}$

Most radical Muslims are totally different from mainstream groups. ${ }^{63}$ Their understanding of the teachings of Islam and their radical views are the result of instant training and short courses. Some of them are even eager to simplify reality by making a basic contrast between what they term "Islamic" and "un-Islamic." However, they are not well equipped with the foundations of the scholarship of Islamic jurisprudence or the Traditions of mainstream Islam, such as $\mathrm{NU}$ and Muhammadiyah possess; instead they rely on their own direct interpretations of the Qur'aßand Hadith.

According to Kuntowijoyo, the tendency to keep a distance from mainstream Islam in terms of ideological and physical interaction has led these younger Muslims to be further detached from the ummah, the Islamic community as a whole. This trend is part of an urban phenomenon in which alienation from wider society and exclusiveness in embracing religion become common. Peer groups and school affiliations become more important than association with conventional Islamic organizations. The kyai and 'ulama $x$ an no longer attract them to study and understand Islam in depth; rather they gain their information and religious knowledge from anonymous sources, such as cassettes, the internet, radio, television and books. ${ }^{64}$ Even though a number of them have gained some mastery of Islamic knowledge, it has not been gained through intensive academic training. Objections to the authority of conventional Islamic organizations and scholars are not uncommon.

Identified by their militancy and strict adherence, as well as their detachment from their elders, this younger generation make themselves more "pious" in their actions than the norm, without necessarily following the views and doctrines of established "ulama? Kuntowijoyo refers to this type of santri as Muslim Tanpa Masjid

\footnotetext{
62 Splinter groups of DI are Komando Jihad, Isa Bugis, Islam Jamaah, Islam Murni and Jemaah Islamiyah while figures, such as Abu Bakar Ba'asyir and Irfan S. Awwas are allegedly known to be associated with DI/NII. Interview with Ismail Yusanto, Canberra, 1 August 2004.

${ }^{63}$ Tamara, Indonesia in the Wake of Islam, p. 6.

${ }^{64}$ Kuntowijoyo, Muslim Tanpa Masjid, p. 130.
} 
(Muslims without Mosques) ${ }^{65}$ or, as the weekly magazine Tempo put it, as "Muslims without Custodians." 66

Strictly speaking, the groups allegedly associated with radical activities in Indonesia since the 1980s are mainly referred to under the general name, NII, which later shifted into the more violent global movement of Jemaah Islamiyah (JI). Besides the movements working for an Islamic state, there are also a number of radical organizations that have targeted their actions towards places of vice. They have launched campaigns against prostitution, gambling, alcohol and drugs, sometimes resorting to physical attacks on places where such unlawful services are provided, such as massage parlours, bars, nightclubs and other sites of entertainment. ${ }^{67}$ Among these, the Front for the Defence of Islam, Front Pembela Islam (FPI), Laskar Jihad and Laskar Jundulllah are radical groups that are not ideologically driven by the goal of an Islamic state but their presence in Indonesia has caused disturbances and has been cause for concern among many nonMuslims.

a) The Islamic State of Indonesia, Negara Islam Indonesia, NII

The Darul Islam movement, founded and led by Kartosuwiryo, who established an Indonesian Islamic State, Negara Islam Indonesia (NII) on 7 August 1949, was finally crushed by the Indonesian army in the early 1960s. However, its informal network has never been totally destroyed. DI-associated underground movements have persisted until the present day. ${ }^{68}$ Instead of uniting themselves under a single leadership, they became separated and fragmented under different leaders. Each group has tried to annul other groups while claiming still to represent the "real" DI. ${ }^{69}$

\footnotetext{
${ }^{65}$ Kuntowijoyo used the term, "Muslim Tanpa Masjid," to identify the phenomenon of young Muslims in 1998. However, the 1970s and 1980s also witnessed the same trend, when many Muslims kept their distance from mainstream Islam. See Kuntowijoyo, Muslim Tanpa Masjid, p. 130.

66 Tempo, 11 April 1981.

${ }^{67}$ See Sidney Jones, "Indonesia: Violence and Radical Muslims" ICG Indonesia Briefing (10 October 2001).

68 Martin van Bruinessen, "Genealogies of Islamic Radicalism in Post-Suharto Indonesia," South East Asia Research, 10 no. 2 (2002), p. 128.

${ }^{69}$ Widjiono Wasis, Geger Talangsari: Serpihan Gerakan Darul Islam (Jakarta: Balai Pustaka, 2001), p. 179.
} 
When the ima of Darul Islam was captured and many of his top deputies pledged allegiance to the government in exchange for amnesty, DI became leaderless. ${ }^{70}$ There was no single person who was considered qualified to take over the leadership. According to DI regulations on the issue of the central leadership, it was stated that any successor to the ima must be chosen from among the regional commanders and the members of the high command. ${ }^{71}$ Since all of these had taken an oath of loyalty to the national government in 1963, the only person who remained committed to the struggle was Abdul Fatah Wirananggapi, but he had been in prison since $1953 .{ }^{72}$ This uncertainty surrounding the central leadership has resulted in confusion among DI veterans in determining to whom loyalty must be given. Some local leaders of DI, who did not abandon the struggle for an Islamic state, started to exercise independent leadership. For instance, Ahmad Sobari who was DI district head of Priangan Timur, West Java, founded the Islamic State of Tejamaya. ${ }^{73}$

Many splinter groups of Darul Islam are not linked directly to DI leaders, but they carry on the struggle for an Islamic state under the leadership of independent, low-ranking comrades. The policy of repression of the New Order towards the movement has led it into considerable disorientation. The important concern for the remaining activists is how to maintain the survival of the struggle for an Islamic state. ${ }^{74}$ They use this analogy: "since the loss of the big ship of DI, which carried out the struggle of the Islamic State, small lifeboats called sekoci (an Indonesian term) must be immediately responsible for saving the struggle of the movement." 75 Some Islamic activists of the 1980s have called those DI-associated movements that have recruited members from the campuses the Kelompok Sekoci (Sekoci Group), and therefore successors to NII. Among those Sekoci groups known for their involvement in violent action during the 1970s and 1980s was the

\footnotetext{
${ }^{70}$ See Sidney Jones, "Recycling Militants in Indonesia: Darul Islam and the Australian Embassy Bombing” ICG Asia Repost no. 92 (22 February 2005), p. 2.

${ }^{71}$ Ibid.

72 “Tanya Jawab Estapeta Pemimpin NII dalam Darurat Perang," 14 September 2002.

73 Jones, "The Recycling Militants in Indonesia," p. 3.

${ }^{74}$ See Tempo, 14 July 2002.

75 Interview, Anonymous, Jakarta 4 March 2003.
} 
Komando Jihad. ${ }^{76}$ Other groups have developed up to the present time under various leaders, such as Abdullah Sungkar, who died in Bogor, West Java in 2000 and was subsequently replaced by Abu Bakar Ba'asyir. Sekoci groups nowadays are known by their clandestine activities. They continue to recruit new members and to obtain financial support to carry out their struggle. Newly inducted members are obliged to make monetary contributions. "Paradise is cheap, my brother. It only costs $20 \%$ of our income." 77 Those who cannot comply with this obligation will receive some form of penalty. Some members even go as far as stealing or robbing banks. ${ }^{78}$

b) Jemaah Islamiyah

The two best-known and allegedly central figures of Jemaah Islamiyah (JI) are Abdullah Sungkar and Abu Bakar Ba'asyir, both of Hadhrami Arab descent. Even though many Indonesian Muslims still question the existence of JI, it has become clear that both Sungkar and Ba'asyir developed a Muslim group, called Jemaah Islam in the 1980s (not Jemaah Islamiyah). ${ }^{79}$ Both terms, "Jemaah Islam" and "Jemaah Islamiyab" have the same meaning; the difference is that the first is Indonesian whereas the second follows Arabic grammar (al-jama alislarizath in full). JI is an expanded version of the Darul Islam organization, formed in part when Ajengan Masduki was appointed to hold the caretaker leadership of DI when most of its leaders were arrested during the case of the Komando Jihad. ${ }^{80}$

The main focus the Masduki cabinet was to develop international linkages and to support and strengthen DI military capacity. Abdullah Sungkar was appointed to assist Masduki in raising funds from Saudi

\footnotetext{
76 See Tempo 30 September 1978.

77 In order to recruit new members, the NII approach was sometimes to kidnap the target and give indoctrination. For further details see "Jalan Pintas ke Surga, Katanya," Tempo, 14 July 2002.

78 There is the NII's concept of fai, raising funds by attacking the enemies of Islam. However, what they call the enemies of Islam are not only non-Muslims but also fellow Muslims who are not members of the movement. For further details, see ICG report, "Al-Qaedah in Southeast Asia: the Case of the Ngruki Networks in Indonesia," Indonesia Briefing (8 August 2002), p. 8.

79 See Tapol, Indonesia: Muslims on Trial (London: the Indonesian Human Rights Campaign, 1987), pp. 91-92.

${ }^{80}$ Jones, “The Recycling Militants in Indonesia," p. 21.
} 
Arabia and the Rakzthy, while another member of the top staff, Mia Ibrahim was asked to send DI recruits to Afghanistan. In 1988, Masduki, accompanied by Abdullah Sungkar, Abu Bakar Ba'asyir and two others, left Indonesia with a DI delegation for Pakistan and Afghanistan. This travel linked DI with Abdul Rasul Sayaf of the Philippines and Abdullah Azam, a senior Mujahidin commander in Afghanistan. ${ }^{81}$ It exposed DI leaders to the challenge of extending their goals towards a broader, international caliphate. The trip gave rise to friction between Masduki and Sungkar, when Masduki, who could not speak Arabic, asked Sungkar to act as spokesman on behalf of the group. Sungkar did all the talking and deliberately excluded Masduki. This competition was intended to demonstrate the dominance of Sungkar over all Afghan veterans. ${ }^{82}$ What is more, Masduki, who was of traditionalist NU inclination, became the target of criticism form the more "pure" Salafi-oriented contingent; Abdullah Sunkar and his networks often accused Masduki of practising what they called "un-islamic mysticism." 83

In the event, the Afghan veterans joined in strengthening JI on their return to Indonesia and contributed to defining the targets of violence as not limited to the local enemy (the Soeharto regime) but to include attacks on what they perceived as the global enemies of Islam, such as the United States, the West and the Zionist conspiracy. Since then, radical Islamic groups in Indonesia have shown their international concerns in terms of their networks and alliances.

\section{Global Santri (the 1990s): The Rise of Jemaah Tarbiyah}

In contrast to their fellow Muslims who have embarked on radical action, there are some of the younger Muslim generation who find themselves unable to identify with either traditionalist or modernist life; they are more interested in trans-national movements. This new type of santri is known by its tendency to take on global issues within the Islamic world and to pay little attention to issues of national interest. ${ }^{84}$ It is a strategy to avoid repression by the regime in power.

\footnotetext{
81 Ibid.

82 Ibid.

${ }^{83}$ Ibid.

84 Even though the elder generation of Indonesian Muslims were influenced by international events to some extent, this younger generation have started to take global inspiration to revitalise Islamic activism in Indonesia. In the past, Muhammadiyah, NU, and Persatuan Islam (Persis) were influenced by an intellectual interaction
} 
Even though most of them have been frustrated and dissatisfied with the regime and its policies, they have sought to choose a different kind of resistance, setting themselves apart from political and social conditions through covert Islamic cultivation and predication, or tarbiyah. 85

Thus one of the most salient characteristics of Indonesian Muslims since the 1980s has been their tendency to connect themselves with global issues and movements. This has undermined the authority of local scholars in dealing with religious issues. They were considered to have been co-opted by the governing regime and so not to speak for the interest of the ummah. The younger generation of Indonesian Muslims has been attracted to foreign movements because of their "original" and "authentic" cachet and their image of not having been manipulated by the state. ${ }^{86}$ Jemaah Tarbiyah has adopted new models in carrying out its da wah activities derived from the Muslim Brothers of Egypt, while other segments of Indonesian Muslims have blatantly imported the modus operandi of Middle Eastern movements into Indonesia, and the Salafi, Hizbut Tahrir and Jemaah Tabligh are examples of trans-national movements at work in Indonesia.

They have attracted many Muslim youths to their new perspectives in understanding social and political realities, by focussing on an Islamic dissemination that is more visionary and organised. ${ }^{87}$ Instead of spending their energies in attacking the government, they have preferred to devout themselves to practising the basic teachings of their religion. They have tried to re-Islamise fellow Indonesian Muslims, particularly the youth and students, by improving the "quality" of individuals in terms of morality and behaviour. Having witnessed the process of forced de-politicisation and Muslim ineffectuality, they have eschewed political struggle in the short term,

\footnotetext{
between Indonesian Muslims and Middle Eastern Muslim in the 20th century. See Martin van Bruinessen, "Global and Local in Indonesian Islam" Southeast Asian Studies 37 no. 2 (1999), pp. 46-63.

${ }^{85}$ In fact, the decision to disengage from political and social realities by focussing on the development of personal piety was a decisive and significant moment that Jemaah Tarbiyah's activists often consider a stage of $k a h f i$, or withdrawal preparatory to action. Interview with Rahmat Abdullah, Jakarta, 11 May 2003.

${ }^{86}$ Interview with Akswendi, Surabaya, 13 March 2003.

87 Ibid.
} 
in order to build gradual and small clusters of cells leading eventually to a massive network. 88

One of the most interesting phenomena of Indonesian Islam in the 1990s has been the rise of the religious movement called Jemaah Tarbiyah in the campuses of secular universities. This name is not a formal name of a movement but rather Muslim activists in campuses reportedly acknowledged this group as Jemaah Tarbiyah or ikhwars? One activist of Jemaah Tarbiyah stated: "We do not name our group, and even the name 'Jemaah Tarbiyah' did not come from us; it is other groups who have named us." 90

It emerged in the mid 1980s, when certain cadres made first contact with and experienced religious training under the moderate wing of the Muslim Brothers of Egypt. Jemaah Tarbiyah proved itself able to channel enthusiastic Muslim students in the state universities by providing religious training and outreach programs. Since the 1990s, activists of Jemaah Tarbiyah have succeeded in gaining control of intra campus student organisations. They have organised Islamic programs and activities for students based in small prayer rooms in campuses and have founded a Forum for Islamic Studies in many faculties. In order to organise Islamic activities among the universities in Java and the Outer Islands, they also began to control the Forum for Coordinating Campus Predication, Forum Silaturahmi Lembaga Dakwah Kampus (FSLDK). Subsequently, through student general elections, they have been able to take over the central leadership of student senate organisations at the faculty and university level. In 1998, after the fall of the Soeharto regime, Jemaah Tarbiyah activists who were active in FSLD founded an extra-campus organisation, the Indonesian Muslim Student Action Union, Kesatuan Aksi Mahasiswa Muslim Indonesia (KAMMI).

The pioneers of Jemaah Tarbiyah are neither from abangan families nor secular backgrounds. They have inherited santri traditions but have gone through different religious and intellectual experiences from their forbears. They are the children and grandchildren of both traditionalist and modernist santri of the 1950s and 1960s. In describing his family's

\footnotetext{
${ }^{88}$ Liddle, “The Islamic Turn,” p. 624.

${ }^{89}$ See "Banyak Jalan Menuju Kehidupan Islami," Suara Hidayatullah, August 2000.

${ }^{90}$ Interview with Aus Hidayat, Depok, 15 May 2003.
} 
religious background, one Jemaah Tarbiyah activist who was a student of the Institute of Technology, ITS, Surabaya in 1982, stated

My family is a transitional one. My grandfather was a religious leader associated with Masyumi and a pious person. In contrast, my father and mother probably had changed [their orientation]. They are like ordinary people in general. [They were] actively involved in non-religious organizations and middle class groups. ${ }^{91}$

On relations between Islam and the state, this group tends to believe that Islam contains both dimensions of religion and state (al-dis wa al-dawlah). While holding the view of the inseparable links between Islam and politics, Jemaah Tarbiyah believes that Islam does not provide a detailed explanation of political and governmental matters. The function of the state is to assure and maintain the survival of religion, while the Islamic parties are a necessary means to bring gradual changes in the state to take a more open stance towards Islam. It was for that reason that after Soeharto's resignation and the end of his regime in 1998, Jemaah Tarbiyah transformed itself into a political party, assuming the name of the Justice Party, Partai Keadilan (PK). This was later changed in 2003 into the Prosperous Justice Party, Partai Keadilan Sejahtera (PKS).

\section{Conclusion}

The emergence of various categories of santri dating from the early establishment of the Soeharto regime to the current situation in Indonesia has shown the dynamics of the santri in Indonesia. This phenomenon is not monolithic but rather has involved many forms of cultural interaction and adaptation. The case of Jemaah Tarbiyah also has shown this tendency, since it shows how its global inclination meets at the interface with local Indonesian traditions.

The processes of Islamisation in Indonesia remain an interesting subject to study. They represent different groups and religious orientations but have same interests, in particular on how they see the role of Islam in society and its relation with the state. Therefore, their presence in Indonesia should not bring conflict among different Islamic groups. They are assumed to contribute in enriching the

${ }^{91}$ Interview with Sigit Susiantomo, Surabaya, 17 March 2003. 
practice of Islam in Indonesia and become model for their fellow around the world, including Muslims in the Middle East. []

\section{Bibliography}

Ahmadsumadi, Sugiat. "HMI, LMD, AMT, ICMI, DI dan Akhirnya Sufi," in Bang 'Imad Pemikiran dan Gerakan Dakwahnya. Jakarta: Gema Insani Press, 2002. 247-251.

Anwar, Syafi'i. Pemikiran dan Aksi Islam Indonesia: Sebuah Kajian Politike Tentang Cendekiawan Muslim Order Baru. Jakarta: Paramadina, 1995.

Assidiqie, Jimly eds. Bang Imad Pemikiran dan Gerakan Dakwahnya. Jakarta: Gema Insani Press, 2002.

Aziz, Abdul. "Meraih Kesempatan dalam Situasi Mengambang: Studi Kasus Kelompok Keagamaan Mahasiswa Univesitas Indonesia," Penamas No. 20 (1995): 3-20.

Azra, Azyumardi. Jaringan Global dan Lokal Islam Nusantara. Bandung: Mizan, 2002.

-..'Kelompok Sempalan di Kalangan Mahasiswa PTU: Anatomi Sosio Historis" in Dinamika Islam di Perguruan Tinggi Wacana Tentang Pendidikan Agama Islam. Jakarta: Logos, 1999. 233-246.

--------."Melacak Pengaruh dan Pergeseran Orientasi Tamatan Cairo," Studia Islamika 2 no. 3, (1995): 141-177.

Barton, Greg. "Islam and Politics in the New Indonesia," in Islam in Asia Changing Political Realities. New Brunswick and London: Transaction Publishers, 2002. 1-89.

Benda, Harry J. "Christian Snouck Hurgronje and the Foundations of Dutch Islamic Policy in Indonesia," The Journal of Modern History 30 no. 4 (December 1958): 338-347.

Boland, B.J. The Struggle of Islam in Modern Indonesia. Leiden: KITLV, 1982.

Bruinessen, Martin van. "Genealogies of Islamic Radicalism in PostSuharto Indonesia," South East Asia Research 10 no. 2 (2002): 117-154.

-. "Post-Suharto Muslim Engagements with Civil Society and Democratisation," in Indonesia in Transition: Rethinking "Civil 
Society', Religion', and 'Crisis.' Yogyakarta: Pustaka Pelajar, 2004. 37-66.

--. Tarekat Naqsyabandiyah di Indonesia. Bandung: Mizan, 1992.

-. "Global and Local in Indonesian Islam", Southeast Asian Studies 37, no.2 (1999): 158-175.

---------. “Gerakan Sempalan di Kalangan Umat Islam Indonesia: Latar Belakang Gerakan Sosial Budaya," in Artikulasi Islam Kultural: dari Tahapan Moral ke Periode Sejarah. Jakarta: RajaGrafindo Persada: 2004. 206-261.

Crouch, Harold. "Islam and Politics in Indonesia" in Politics, Diplomacy and Islam: Four Case Studies. Canberra: Department of International Relations the Australian National University, 1986. 15-30

Damanik, Ali Said. Fenomena Partai Keadilan:Transformasi 20 Tahun Gerakan Tarbiyah di Indonesia. Bandung, Mizan, 2002.

Dodge, Bayard. Al-Azhar: A Millenium of Muslim Learning. Washington DC: The Middle East Institute, 1961.

Douglas, Ramage. Politics in Indonesia: Democracy, Islam and the Ideology of Tolerance. New York: Routledge, 1995.

Douglas, Stephen A. Political Socialization and Student Activism in Indonesia. Urbana: University of Illinois Press, 1970.

Effendy, Bahtiar. Islam dan Negara: Transformasi Pemikiran dan Praktik Politik Islam di Indonesia. Jakarta: Paramadina, 1998.

---------. Teologi Baru Politik Islam Pertautan Agama, Negara dan Demokrasi. Jakarta: Galang Press, 2001.

Esposito, John L. and John O Voll. Islam and Democracy. New York: Oxford University Press, 1996.

Esposito, John L. ed. The Oxford Encyclopaedia of the Modern Islamic World. New York: Oxford University Press, 1995.

Feillard, Andree "Traditionalist Islam and the State in Indonesia" in Islam in an Era of Nation States:Politics and Religious Renewal in Muslim Southeast Asia. Honolulu: University of Hawaii Press, 1997.

Fischer, Joseph and Sudarsono, Juwono. "Indonesian Student Activism," Pacific Affairs 44 no. 1 (Spring, 1971): 92-96. 
Fuller, Graham E. "Islamism(s) in the Next Century," in The Islamism Debate. Tel Aviv: Moshe Dayan Center for Middle Eastern and African Studies, 1997. 140-173.

Furkon, Aay Muhammad. Partai Keadilan Sejabtera Ideologi dan Praksis Politik. Kaum Muda Muslim Indonesia Kontemporer. Bandung: Teraju, 2004.

Geertz, Clifford. Islam Observed Religious Development in Morocco and Indonesia. Chicago and London: University of Chicago Press, 1968.

------. The Religion of Java. New York: The Free Press, 1960.

Hasan, Muhammad Kamal. Muslim Intellectual Responses to New Order Modernisation in Indonesia. Kuala Lumpur: Dewan Bahasa and Pustaka, 1980.

Hefner, Robert W. "Islamising Java? Religion and Politics in Rural East Java," Journal of Asian Studies 46 no. 3 (Augustus, 1987), 533-554.

------. "Islam, State, and Civil Society: ICMI and the Struggle for the Indonesian Middle Class," Indonesia 56 (October 1993): 1-35.

-------. Civil Islam: Muslim and Democratisation in Indonesia. Princeton and Oxford: Princeton University Press, 2000.

Jones, Sidney "Indonesia Backgrounder: Why Salafism and Terrorism Mostly Don't Mix," ICG Asia Report no. 83 (13 September 2004).

---------. "Radical Islam in Central Asia: Responding to Hizb UtTahrir” ICG Asia Report, no. 58 (30 June 2003).

. "The Recycling Militants in Indonesia: Darul Islam and the Australian Embassy Bombing” ICG Asia Report no. 92 (22 February 2005).

-. "It Can't Happen Here: A Post-Khomeini Look at Indonesian Islam," Asian Survey 20 no. 3 (March 1980): 311-323.

------. "Al-Qaedah in Southeast Asia: the Case of the Ngruki Networks in Indonesia," Indonesia Briefing (8 August 2002).

-------. "Indonesia: Violence and Radical Muslims" ICG Indonesia Briefing (10 October 2001). 
Karim, M. Rusli. HMI MPO dalam Kemelut Modernisasi Politik di Indonesia. Bandung: Mizan, 1997.

Koentjaraningrat, Javanese Culture. Singapore: Oxford University, 1985.

Kramer, Martin, ed. The Islamism Debate. Ramat Aviv: Tel Aviv University, 1997.

Kuntowijoyo, Muslim Tanpa Masjid. Bandung: Mizan, 2001.

Liddle, R. William. “Soeharto's Indonesia: Personal Rule and Political Institutions," Pacific Affairs 58 no. 1 (Spring, 1985): 68-90.

-. "Media Dakwah Scriptualism: One Form Islamic of Political Thought and Action in New Order Indonesia" in Toward a New Paradigm: Recent Developments in Indonesian Islamic Thought. Tempe: Arizona State University, 1996. 323-356.

-. "The Islamic Turn in Indonesia: A Political Explanation," The Journal of Asian Studies 55 no. 3 (August, 1996): 613-634.

Lufhfi, AM. "Gerakan Dakwah di Indonesia," in Bang Imad Pemikiran dan Gerakan Dakwah. Jakarta: Gema Insani Press, 2002. 158-163.

Machmudi, Yon. Partai Keadilan Sejabtera: Wajah Baru Islam Politik Indonesia. Bandung: Harakatuna Publishing, 2005.

Madjid, Nurcholish. "Agama dan Negara dalam Islam," in Kontekstualisasi Doktrin Islam dalam Sejarah. Jakarta: Paramadina, 1994. 588-594.

Madjid, Nurcholish. "Cita-Cita Politik Kita" in Aspirasi Umat Islam di Indonesia. Jakarta: Leppenas, 1983. 7-36.

Mehden, Fred R. von der Two Worlds of Islam: Interaction between Southeast Asia and the Middle East. Gainesville: the University Press of Florida, 1993.

Naipaul, V.S. Among the Believers: an Islamic Journey. New York: Vintage Books, 1982.

Pranowo, Bambang. "Islam and Party Politics in Rural Java," Studia Islamika I no. 2 (1994): 1-19.

Putra, Heddy Shri Ahimsa. "Ramadhan di Kampus, PNDI, dan Safari Ramadhan: Beberapa Pola Islamasasi di Masa Order Baru” in Agama Spiritualisme dalam Dinamika Ekonomi Politik. Surakarta: Universitas Muhammadiyah Surakarta, 2001. 11-22. 
Roff, William R. The Origins of Malay Nationalism. Kuala Lumpur: Universiti Malaya, 1980.

Roy, Olivier. The Failure of Political Islam, trans. Carol Volk. Massachusetts: Harvard University Press, 1994.

-------. The Globalised Islam: the Search for a Global Ummah. London: C. Hurst, 2002.

Saidi, Ridwan. "Dinamika Kepemimpinan Islam," in Islam in Indonesia: Suatu Ikbtiar Mengaca Diri. Jakarta: CV Rajawali, 1986. 81-96.

Samson, Allan A. "Army and Islam in Indonesia," Pacific Affairs 44 no. 4 (Winter, 1971-1972): 545-565.

-----.- "Islam and Indonesian Politics," Asian Survey 8 no. 12 (December 1968): 1001-1017.

Schwarz, Adam. A Nation in Waiting: Indonesia's Search for Stability. St. Leonards: Allen and Unwind, 1999.

Tamara, Nasir. Indonesia in the Wake of Islam: 1965-1985. Kuala Lumpur: Institute of Strategic and International Studies, 1986.

The American Heritage ${ }^{\circledR}$ Dictionary of the English Language, 4 rd ed. Boston: Houghton Mifflin, 2000.

Tholkhah, Imam and Abdul Aziz. "Gerakan Islam Kontemporer di Indonesia: Sebuah Kajian Awal," in Gerakan Islam Kontemporer di Indonesia. Jakarta: Pustaka Firdaus, 1996. 1-20.

Tibbi, Bassam. Islam and the Cultural Accommodation of Social Change. San Francisco: Westview Press, 1991.

Tim Amnesti Internasional. Fakta Diskriminasi Rezim Soeharto Terhadap Umat Islam, trans. Mohammad Thalib. Yogyakarta: Wihda Press, 1988.

Voll, John Obert. Islam Continuity and Change in the Modern World. Essex: Westview Press, 1982.

Waardenburg, Jacques "Muslim and Other Believers: The Indonesian Case" in Islam in Asia II . (Boulder: Westview Press, 1984), 3233.

Ward, Ken. The 1971 Election in Indonesia: An East Java Case Study. Clayton: Centre of Southeast Asian Studies Monash University, 1974. 
Wasis, Widjiono. Geger Talangsari: Serpihan Gerakan Darul Islam. Jakarta: Balai Pustaka, 2001.

\section{Newspapers}

Kompas, 17 June 2003.

Suara Hidayatullah, August 2000.

Tempo, 30 September 1978.

Tempo, 14 July 2002.

Tempo, 3 April 1993.

Tempo, 14 July 2002.

Tempo, 11 April 1981.

\section{Interviews}

Interview with Ismail Yusanto, Canberra, 1 August 2004.

Interview with Rahmat Abdullah, Jakarta, 11 May 2003.

Interview with Akswendi, Surabaya, 13 March 2003.

Interview with Aus Hidayat, Depok, 15 May 2003.

Interview with Nur Mahmudi, Depok, 8 May 2003.

Interview with Rahmat Abdullah, Jakarta, 11 May 2003.

Interview with Sholeh Drehem, Surabaya, 13 March 2003.

Interview with Sigit Susiantomo, Surabaya, 17 March 2003. 